\title{
STUDI KONTAMINASI Escherechia coli PADA PERALATAN MAKAN (GELAS) YANG DIGUNAKAN OLEH PEDAGANG ES DAWET DI KECAMATAN SOKARAJA KABUPATEN BANYUMAS TAHUN 2015
}

\author{
Akbar Sandi Perdana'), Dwi Bayu Karti Utami' ${ }^{2}$ \\ Jurusan Kesehatan Lingkungan, Politeknik Kesehatan Kemenkes Semarang, \\ Jl. Raya Baturaden KM 12 Purwokerto, Indonesia
}

\begin{abstract}
Abstrak
Kebersihan peralatan makan yang kurang baik mempunyai peranan penting dalam penyebaran kuman penyakit dan keracunan.Permasalahan penjual es dawet mencuci peralatan makanan atau minuman menggunakan air sumur tercemar.Tujuan penelitian ini adalah untuk mengetahui keberadaan E. coli pada peralatan makan (gelas) yang digunakan oleh pedagang es dawet di Kecamatan Sokaraja Kabupaten Banyumas.Metode penelitian yang digunakan adalah metode deskriptif dengan analisa laboratorium untuk mengetahui angka bakteri E.coli pada alat makan yang digunakan oleh pedagang es dawet.Hasil pemeriksaan laboratorium usap peralatan makan yang digunakan oleh pedagang es dawet belum memenuhi syarat kesehatan sesuai dengan Permenkes RI No. 1096/Menkes/PER/2011 adalah bahwa syarat peralatan makan tidak mengandung E.coli. Pada 5 sampel peralatan makan gelas yang digunakan oleh pedagang es dawet semuanya mengandung kuman E.coli (positif), hasil pemeriksaan menunjukan sampel gelas Toh ditemukan 50, sampel gelas An 230, sampel gelas Dar 230, sampel gelas Sul >24.000 dan sampel gelas Fua 3500. Sebaiknya pegagang lebih menjaga kebersihan hygiene sanitasi makanan terutama pada proses pencucian alat makan sehingga sangat kecil kemungkinan terjadinya kontaminasi pada makanan.
\end{abstract}

Kata kunci : Escherechia coli, alat makan

Abstract

[Escherechia coli contamination studies on tableware (glass) used by traders ice dawet in the district Sokaraja Banyumas regency 2015]. Cleanliness unfavorable tableware has an important role in the spread of germs and poisoning. Problems ice dawet washing equipment sellers of food or drink contaminated well water use. The purpose of this study was to determine the presence of E.coli in tableware (glass) used by the merchant ice dawet in District Sokaraja Banyumas. The method used is descriptive method by laboratory analysis to determine the numbers of E.coli in the cutlery used by the merchant ice dawet. Results of laboratory tests swab tableware used by the merchant ice dawet not meet health requirements in accordance with Permenkes No. 1096/Menkes/PER/2011 is that the requirement does not contain E.coli cutlery. At 5 sample glass tableware used by the merchant ice dawet all contain E.coli bacteria (positive), the results showed samples glass Toh found 50, sample cups An 230, sample cups Dar 230, sample cups Sul> 24,000 and a glass sample Fua 3500. Should pegagang over maintaining cleanliness of food sanitation hygiene especially in the process of washing cutlery so very small possibility of contamination in food.

Keywords : Escherechia coli, cutler

\section{PENDAhuluan}

Makanan dan minuman yang memenuhi syarat kesehatan, maka perlu diadakan pengawasan terhadap hygiene dan sanitasi makanan dan minuman. Utamanya adalah usaha diperuntukkan untuk umum seperti restoran, rumah makan, ataupun pedagang kaki lima mengingat bahwa makanan dan minuman merupakan media yang potensial penyebaran penyakit (Depkes RI, 2004).

Di Indonesia peraturan telah dibuat dalam bentuk Permenkes RI No. 1096/MENKES/PER/VI/2011, bahwa untuk persyaratan peralatan makan angka kuman pada peralatan makan 0 (nol) dan tidak mengandung Escherechia coli (E.coli).Persyaratan mikrobiologi E.coli dipilih sebagai indikator tercemarnya air atau makanan, karena keberadaan bakteri E.coli dalam sumber air atau makanan merupakan indikasi pasti terjadinya kontaminasi tinja manusia maupun tinja hewan (Candra, 2006). Adanya E.coli menunjukan suatu tanda praktek sanitasi yang tidak baik karena E.coli bisa dipindah sebarkan dengan kegiatan tangan kemulut atau dengan pemindahan pasif lewat makanan, air, susu dan produk-produk lainya (Supardi, 1999).

2) E-mail:dwibayukartiutami@gmail.com 
Bedasarkan hasil observasi pendahuluan yang dilakukan oleh peneliti terdapat lima penjual es dawet di Kecamatan Sokaraja Kabupaten Banyumas yang mengunakan air sumur untuk mencuci peralatan makan dari lima pedagang yang di observasi pendahuluan oleh peneliti.Selain mengunakan air sumur pedagang juga tidak pernah mengganti air dalam bak pembilas, tempat penjualan terletak di pinggir jalan yang ramai, serta dagangan pedagang yang laku keras penjualannya.

Tujuan penelitian ini untuk mengetahui "Keberadaan E.coli pada peralatan makan yang digunakan oleh pedagang es dawet di Kecamatan Sokaraja Kabupaten Banyumas".

\section{BAHAN DAN METODE}

Penelitian ini merupakan jenis penelitian deskriptif dengan pemeriksaan di laboratorium yang bertujuan untuk mendeskripsikan angka E.coli yang terdapat pada alat makan yang digunakan oleh pedagang es dawet di Kecamatan Sokaraja Kabupaten Banyumas.

Metode pengambilan sampel yang digunakan adalah purposive sampling dengan kriteria penjual es dawet adalah berjualan dengan cara menetap, dekat dengan sumber air, tempat penjualan di pinggir jalan yang ramai, dan pedagang yang laku keras penjualannya. Berdasarkan kriteria tersebut didapatkan 5 (lima) sampel pedagang es dawet di Kecamatan Sokaraja Kabupaten Banyumas.

Data dianalisis secara univariat dengan menggunakan analisis deskriptif berupa prosentase terhadap data-data yang tertera dalam tabel kemudian dituangkan dalam bentuk narasi secara deskriptif. Diperoleh dari observasi proses pencucian peralatan makan dengan menggunakan checklist dan kuesioner serta data pemeriksaan usap alat makan diperoleh dari hasil analisis laboratorium untuk mengetahui berapa angka E.coli pada peralatan makan yang digunakan oleh pedagang es dawet, kemudian hasil dari laboratorium dibandingkan dengan Permenkes RI. No. 1096/Menkes/Per/VI/2011 apakah alat makan tersebut memenuhi syarat atau tidak memenuhi syarat.

\section{III.HASIL DAN PEMBAHASAN}

\section{HASIL}

Hygiene sanitasi alat makan pedagang es dawet di Kecamatan Sokaraja Kabupaten Banyumas, kode sampel Toh memperoleh skor 70,37\%, sampel An memperoleh skor $74,07 \%$, sampel Dar memperoleh skor $74,07 \%$, sampel Sul memperoleh skor 70,37\% dan sampel Fua memperoleh skor $70,37 \%$ sehingga semua pedagang sudah memenuhi syarat.

Proses pencucian peralatan makan pada pedagang es dawet di Kecamatan Sokaraja Kabupaten Banyumas terdapat 4 pedagang yang diteliti belum memenuhi syarat kesehatan dengan presentase hasil pemeriksaan kode sampel Toh dengan skor 52,94\%, sampel An dengan skor 52,94\%, sampel Sul 44,44\% sampel Fua 52,94\%, dan 1 pedagang sudah memenuhi syarat sesuai dengan proses pencucian pada Depkes RI 2006 dengan prosentase skor $58,94 \%$.

Hasil pemeriksaan Escherechia coli pada alat makan (gelas) yang digunakan oleh pedagang es dawet di Kecamatan Sokaraja Kabupaten Banyumas, semua sampel tidak memenuhi syarat karena dalam Permenkes No. 1096/MENKES/PER/VI/2011 yang disajikan dalam pernyataan jasa boga bahwa untuk persyaratan peralatan makan angka kuman pada alat makan 0 (nol) dan tidak mengandung E.coli. sampel gelas Toh ditemukan 50, sampel gelas An 230, sampel gelas Dar 230, sampel gelas Sul >24.000 dan sampel gelas Fua 3500.

\section{PEMBAHASAN}

\section{Hygiene sanitasi alat makan}

Pedagang es dawet yang diperiksa di Kecamatan Sokaraja Kabupaten Banyumas semua sudah memenuhi syarat dalam aspek hygiene sanitasi alat makan karena total skor masingmasing pedagang sudah masuk dalam kriteria cukup baik seperti terdapat pada tabel 4.3 tetapi masing-masing pedagang masih harus membenahi aspek-aspek dalam hygiene sanitasi alat makan yang belum dilaksanakan.

a. Perilaku penjamah makanan

1) Personal hygiene

Pedagang es dawet di Kecamatan Sokaraja Kabupaten Banyumas semua sampel yang diperiksa sudah cukup baik dalam aspek personal hygiene, dari 5 pedagang keseluruhan sudah berpakain bersih, berkuku pendek, dan sudah menjaga kebersihan rambutnya, tetapi semua pedagang masih belum mengunakan penutup kepala saat berjualan, penutup kepala berfungsi untuk mencegah adanya cemaran kotoran yang terbawa oleh rambut yang dapat mengontaminasi makanan yang akan disajikan.

Pedagang es dawet di Kecamatan Sokaraja Kabupaten Banyumas keseluruhan tidak mengunakan celemek, sehingga beresiko terhadap debu dan kotoran yang menempel pada pakaian akan mengontaminasi makanan yang akan disajikan. Seluruh pedagang es dawet yang di teliti diketahui tidak ada yang memiliki penyakit kulit sehingga peralatan makan dan makan yang disajikan tidak beresiko terhadap penyebaran penyakit kulit (Permenkes RI No. 1096/Menkes/PER/2011).

2) Perilaku penjamah

Penjamah makanan berdasarkan perilaku pada pedagang es dawet di Kecamatan Sokaraja Kabupaten Banyumas diketahui seluruh pedagang yang diperiksa tidak 
batuk atau bersin dan tidak merokok saat berjualan sehingga makanan dan alat makan tidak akan terkontaminasi penyakit menular dari penjual. Pada saat berjualan diketahui terdapat 5 pedagang yang mengobrol saat berjualan sehingga masih terdapat kemungkinan makanan yang disajikan akan terkena air liur yang dikeluarkan oleh pedagang. Pedagang juga tidak sering melakukan kontak antara tangan dengan peralatan makan sehingga dapat mengurangi kontaminasi antara tangan yang mungkin membawa debu dan bakteri dengan peralatan makan (Permenkes RI No. 1096/Menkes/PER/2011).

3) Ketentuan peralatan makan

Ketentuan peralatan makan yang digunakan oleh pedagang es dawet di Kecamatan Sokaraja Kabupaten Banayumas sudah dilaksanakan oleh para pedagang seperti peralatan makan mudah dibersihkan, peralatan makan yang kontak langsung dengan makanan tidak boleh ada sudut mati (halus), alat makan dan masak yang sekali pakai tidak dipakai ulang hanya saja masih ada 2 pedagang yang mengunakan peralatan makan yang tidak dalam keadaan utuh atau retak peralatan yang sudah retak, atau pecah selain dapat menimbulkan kecelakaan (melukai tangan) juga menjadi sumber pengumpulan kotoran karena tidak akan dapat tercuci sempurna. Demikian pula bila berukir hiasan, hiasan merk atau cat pada permukaan tempat makan tidak boleh digunakan (Depkes RI, 1994 dalam pohan 2009).

4) Sistem pencucian

Pedagang es dawet di Kecamatan Sokaraja Kabupaten Banyumas sudah melakukan sistem pencucian dengan benar seperti membuang sisa makanan atau kotoran pada peralatan makan yang akan dicuci agar supaya sisa makanan yang tertinggal tidak mengeras, sedangkan dalam sistem pencucian peralatan makan pedagang belum mengunakan sistem 3 bak pencucian, pedagang hanya mengunakan bak pencuci dan bak pembilas. Terdapat satu pedagang yang diketahui melakukan sistem pencucian tidak mengunakan detergen dan semua pedagang tidak melakuan sistem pencucian sanitasi dan desinfeksi padahal sistem ini sangat penting karena peralatan makan yang telah dicuci harus bersih dan dijamin aman dari mikroba. Pembersihan dan sanitasi yang kurang baik dapat menyebabkan peralatan makan menjadi perantara penyebaran penyakit dari penjamah yang terinfeksi (Stokes, 1984).

5) Tempat penyimpanan peralatan makan Pedagang es dawet di Kecamatan Sokaraja Kabupaten Banyumas terdapat 5 pedagang yang tidak menyimpan peralatan makan dalam keadaan kering sehingga kemungkinan kontaminasi debu akan sangat mudah menempel pada alat makan. Seluruh pedagang juga sudah menggunakan rak penyimpanan anti karat, tidak aus/rusak dan tempat penyimpanan peralatan makan juga dalam keadaan bersih dari kotoran. Semua pedagang yang diteliti tidak mempunyai laci-laci penyimpanan peralatan sehingga kemungkinan terdapat pencemaran debu terhadap alat makan, serta cangkir, mangkok, gelas dan sejenisnya cara penyimpanannya secara tebalik (Permenkes RI No. 304 tahun 1989).

\section{Proses pencucian alat makan}

Pedagang es dawet di Kecamatan Sokaraja Kabupaten Banyumas tentang proses pencucian peralatan makan terdapat 4 pedagang yang belum memenuhi syarat kesehatan sesuai dengan Depkes RI (2006). Proses pencucian yang baik adalah dengan melakukan proses membuang sisa kotoran, merendam dalam air, mencuci dengan detergen, membilas dengan air bersih, membebashamakan, dan pengeringan.

Proses pencucian peralatan makan yang digunakan pedagang es dawet mengunakan air sumur gali untuk mencuci peralatan makan, karena sarana air di alam pada umumnya mengandung kuman atau bakteri, baik air hujan, air tanah maupun air sungai. Jumlah dan jenis bakteri bervariasi dan berbeda sesuai dengan tempat dan kondisi yang mempengaruhinya. Idealnya air bersih tidak mengandung organisme pathogen, harus juga bebas dari bakteri yang menunjukan indikasi pengotoran tinja. Bakteri E.coli pada umumnya mempunyai jumlah yang besar dari tinja manusia, jadi pendeteksiannya perlu dilakukan setelah beberapa kali tingkat pengenceran.Terdapatnya organisme E.coli lebih meyakinkan adanya tanda-tanda pengotoran tinja (Sunarjo, 1994).

Proses pencucian yang dilakukan oleh pedagang es dawet di Kecamatan Sokaraja Kabupaten Banyumas diketahui bahwa seluruh pedagang yang di teliti sudah mengunakan bak pencuci dan bak pembilas. Pencucian dilakukan dalam bak pertama yang berisi larutan detergen hangat, suhu yang digunakan berkisar antara 43$49^{\circ} \mathrm{C}$, bak kedua Pembilasan dilakukan dalam bak kedua dengan mengunakan air hangat. Pembilasan ini dimaksudkan untuk menghilangkan sisa detergen dan kotoran. Air bilasan harus sering diganti dan akan lebih baik 
bila dilakukan pada air mengalir. Bak ketiga berfungsi sebagai desinfeksi (Hiasinta 2001).

Adanya bak pembilas pada proses pencucian peralatan makan berfungsi untuk menghilangkan sisa-sisa kotoran yang menempel pada peralatan makan yang mungkin belum bersih saat proses pencucian sebelum alat makan tersebut digunakan kembali. Berdasarkan hasil penelitian di pedagang es dawet di Kecamatan Sokaraja Kabupaten Banyumas, semua pedagang juga tidak melakukan proses pencucian peralatan makan dengan mengunakan desinfektan, sehingga hal ini tidak sesuai dengan Depkes (2006), yang menyatakan bahwa cara desinfektan yang umum dilakukan yaitu dengan mengunakan air panas $80^{\circ} \mathrm{C}-100^{\circ} \mathrm{C}$ selama $1-5$ detik, larutan chlor aktif (50ppm), dengan udara panas (oven), sinar ultraviolet dan uap panas.

Proses pencucian pedagang es dawet yang berada di Kecamatan Sokaraja Kabupaten Banyumas tentang proses pencucian alat makan pedagang tidak ada yang membersihkan tangannya terlebih dahulu sebelum mencuci peralatan makan, pedagang umumnya belum mencuci tangan sebeum bekerja dan setelah kembali ke toilet dan pedagang juga sering tidak mengunakan celemek saat bekerja. Hal ini dapat menimbulkan kontaminasi bakteri yang akan dicuci. Mencuci tangan terlebih dahulu dimaksudkan agar tidak ada kontaminasi bakteri dari tangan petugas atau penjamah (Borja, 2008).

Pedagang es dawet di Kecamatan Sokaraja Kabupaten Banyumas seluruhnya membuang sisa makanan atau kotoran pada peralatan makan yang akan dicuci agar supaya sisa makanan yang tertinggal tidak mengeras. Sedangkan dalam hal mencuci peralatan makan tidak ada pedagang yang merendam peralatan makan sebelum dicuci karena menurut pedagang proses merendam peralatan makan terlalu lama dan karena alat makan yang ada tidak tersedia terlalu banyak. Perendaman peralatan makan dimaksudkan untuk memberikan kesempatan alat makan untuk peresapan air kedalam sisa makanan yang menempel atau mengeras sehingga jadi medah untuk di lepas atau dibersihkan dari alat makan (Depkes 2006).

Terdapat 4 Pedagang es dawet juga melakukan proses pencucian dengan mengunakan detergen, sehingga sisa makanan dan lemak-lemak yang menempel pada alat makan mudah untuk dibersihkan sedangkan terdapat 1 pedagang tidak mengunakan detergen sehingga kemungkinan alat makan akan tetap kotor setelah dicuci. Pedagang juga sudah melakukan proses pembilasan pada alat makan yang sudah dicuci, setiap peralatan yang dibersihkan dibilas dengan cara di gosokgosok dengan tangan sampai terasa kesat dan tidak licin. Bila masih terasa licin alat makan mungkin masih mengandung lemak atau sisa sabun yang belum terbilas bersih sehingga dapat menimbulkan bau amis atau anyir. Pedagang juga belum melakukan desinfeksi (membebas hamakan) peralatan makan padahal proses ini sangat penting karena peralatan makan yang telah dicuci harus bersih dan diajamin aman dari mikroba.

Pedagang es dawet di Kecamatan Sokaraja Kabupaten Banyumas juga tidak melakukan proses pencucian peralatan makan dibawah kucuran air kran atau air mengalir karena memang tidak tersedianya kran di tempat pedagang es dawet, hal ini menyebabkan pedagang kurang baik dalam hal pencucian peralatan makan. Kebiasaan pedagang yang yang selalu menempatkan air pada suatu wadah penampungan seperti ember, padahal air yang digunakan tidak pernah diganti dan digunakan berulang-ulang sehingga kontaminasi bakteri sangat mudah untuk menempel pada alat makan yang akan dicuci. Kondisi ini tidak memenuhi syarat kesehatan hygiene sanitasi jasa boga bahwa peralatan hendaknya langsung dicuci dibawah kran dengan air yang mengalir untuk menghindari adanya bakteri pada air yang digunakan berulangulang terebut.

Proses pencucian yang dilakukan oleh pedagang es dawet di Kecamatan Sokaraja Kabupaten Banyumas semua pedagang belum mengunakan air panas dalan proses pencucian peralatan makan, menurut Jenie (1996) ada upaya sanitasi dengan metode mengunakan air panas dapat dilakukan dengan merendam alat-alat makan dalam air panas bersuhu $80^{\circ} \mathrm{C}$ atau lebih. Energi panas diperkirakan menyebabkan denaturasi protein dalam sel mikroorganisme yang akan menyebabkan kematiannya. Metode ini cukup efektif dan dapat diterapkan pada hampir semua jenis permukaan yang bersentuhan dengan makanan. Meskipun demikian cara ini juga memiliki kelemahan karena tidak dapat mematikan spora bakteri yang tahan panas. Spora bakteri biasanya tetap hidup meskipun berada pada suhu air mendidih selama 1 jam.Suhu air panas yang digunakan sangat menentukan waktu kontak yang harus dipenuhi untuk menjalin efektifitas metode sanitasi ini. Pada prinsipnya semakin tinggi suhu air panas yang digunakan, waktu kontak yang diperlukan semakin pendek, air panas bersuhu $80^{\circ} \mathrm{C}$ misalnya, memerlukan waktu kontak 20 menit, sedangkan air panas bersuhu $85^{\circ} \mathrm{C}$ hanya memerlukan waktu kontak 15 menit. Metode ini banyak dipilih untuk sanitasi peralatan makan pada usaha pelayanan jasa boga, alasanya adalah karena air mudah didapat dan tidak beracun (Hiasinta, 2001).

Pedagang juga belum melakukan proses desinfeksi dengan mengunakan klorin maupun iodine padahal desinfektan dengan mengunakan klorin bisa membunuh berbagai spektrum jenis 
mikroorganisme seperti bakteri gram positif maupun negatif, dan spora bakteri, konsentrasi yang diperlukan agar klorin efektif untuk membunuh mikroorganisme adalah 50-100 ppm dengan waktu kontak sekitar 1 menit dan untuk desinfektan dengan iodine (yodofor), yodofor bersifat stabil memiliki umur simpan yang panjang, aktif mematikan hampir semua sel bakteri, tetapi tidak efektif untuk mematikan spora. Aplikasi yodofor untuk desinfektan adalah pada konsentrasi 12-25 ppm dengan kontak 1 menit atau lebih (Hiasinta 2001).

Proses setelah pencucian peralatan yang dilakukan pedagang es dawet adalah meniriskan/memiringkan atau membalik alat makan yang setelah selesai dicuci alasnya adalah agar air yang masih tertinggal pada alat makan sudah tidak ada saat alat makan itu akan digunakan kembali. Setelah alat makan ditiriskan dan ditempatkan pada tempat penyimpanan, pedagang juga mengunakan lap yang bersih untuk menghilngkan sisa kotoran yang mungkin masih menempel atau tertinggal saat proses pencucian seperti noda detergen dan sebagainya. Sebenarnya kalau proses pencucian dilakukan dengan benar maka noda-noda itu tidak terjadi. Prinsip mengunakan lap setelah proses pencucian sebenarnya tidak boleh dilakukan karena akan terjadi kontaminasi skunder dan bila akan mengunakan lap sebaiknya lap yang digunakan hanya sekali pakai (single use) (Depkes, 2006).

\section{Pemeriksaan E.coli pada peralatan makan}

Hasil yang diperoleh dari laboratorium pada 5 sampel pedagang es dawet yang diambil sampel usap alat makan (gelas) semua sampel positif terdapat bakteri E.coli. Hal ini dimungkinkan pada proses pencucian peralatan makan belum baik dan belum memenuhi syarat kesehatan yang tercantum dalam Depkes RI (2006). Proses pencucian yang baik adalah dengan melakukan proses membuang sisa kotoran, merendam dalam air, mencuci dengan detergen, membilas dengan air bersih, membebashamakan, dan pengeringan.

Proses pencucian seluruh pedagang yang di teliti sudah mengunakan bak pencuci dan bak pembilas. Pencucian dilakukan dalam bak pertama yang berisi larutan detergen hangat, suhu yang digunakan berkisar antara $43-49^{\circ} \mathrm{C}$, bak kedua pembilasan dilakukan dalam bak kedua dengan mengunakan air hangat.Pembilasan ini dimaksudkan untuk menghilangkan sisa detergen dan kotoran. Air bilasan harus sering diganti dan akan lebih baik bila dilakukan pada air mengalir. Bak ketiga berfungsi sebagai desinfeksi (Hiasinta 2001), tetapi dalam bak pembilas pedagang hanya mengunakan air yang ditampung dalam bak penampung ember tidak mengunakan air yang mengalir dan air yang digunakan tidak pernah diganti selain itu pedagang juga tidak melakukan proses desinfektan peralatan makan.

Pedagang es dawet juga melakukan proses pencucian alat makan pedagang tidak ada yang membersihkan tangannya terlebih dahulu sebelum mencuci peralatan makan, pedagang umumnya belum mencuci tangan sebeum bekerja dan setelah kembali ke toilet dan pedagang juga sering tidak mengunakan celemek saat bekerja. Hal ini dapat menimbulkan kontaminasi bakteri yang akan dicuci. Mencuci tangan terlebih dahulu dimaksudkan agar tidak ada kontaminasi bakteri dari tangan petugas atau penjamah (Borja, 2008).

Pedagang es dawet di Kecamatan Sokaraja Kabupaten Banyumas terdapat 5 pedagang yang tidak menyimpan peralatan makan dalam keadaan kering sehingga kemungkinan kontaminasi debu akan sangat mudah menempel pada alat makan. Semua pedagang yang diteliti juga tidak mempunyai laci-laci penyimpanan peralatan sehingga kemungkinan terdapat pencemaran debu terhadap alat makan (Permenkes RI No. 304 tahun 1989).

Terdapat 1 pedagang tidak mengunakan detergen sehingga kemungkinan alat makan akan tetap kotor setelah dicuci. Pedagang juga belum melakukan desinfeksi (membebas hamakan) peralatan makan padahal proses ini sangat penting karena peralatan makan yang telah dicuci harus bersih dan diajamin aman dari mikroba.

Pedagang es dawet di Kecamatan Sokaraja Kabupaten Banyumas juga tidak melakukan proses pencucian peralatan makan dibawah kucuran air kran atau air mengalir karena memang tidak tersedianya kran di tempat pedagang es dawet, hal ini menyebabkan pedagang kurang baik dalam hal pencucian peralatan makan. Kebiasaan pedagang yang yang selalu menempatkan air pada suatu wadah penampungan seperti ember, padahal air yang digunakan tidak pernah diganti dan digunakan berulang-ulang sehingga kontaminasi bakteri sangat mudah untuk menempel pada alat makan yang akan dicuci. Kondisi ini tidak memenuhi syarat kesehatan hygiene sanitasi jasa boga bahwa peralatan hendaknya langsung dicuci dibawah kran dengan air yang mengalir untuk menghindari adanya bakteri pada air yang digunakan berulangulang terebut.

\section{IV.Simpulan}

Hygiene sanitasi alat makan pedagang es dawet di Kecamatan Sokaraja Kabupaten Banyumas, kode sampel Toh memperoleh skor 70,37\%, sampel An memperoleh skor 74,07\%, sampel Dar memperoleh skor $74,07 \%$, sampel Sul memperoleh skor 70,37\% dan sampel Fua memperoleh skor 70,37\% sehingga semua pedagang sudah memenuhi syarat, walaupun sudah memenuhi syarat masih ada aspek-aspek yang harus dibenahi oleh pedagang. 
Proses pencucian peralatan makan pada pedagang es dawet di Kecamatan Sokaraja Kabupaten Banyumas terdapat 4 pedagang yang diteliti belum memenuhi syarat kesehatan dengan presentase hasil pemeriksaan kode sampel Toh dengan skor 52,94\%, sampel An dengan skor 52,94\%, sampel Sul 44,44\% sampel Fua 52,94\%, dan 1 pedagang sudah memenuhi syarat sesuai dengan proses pencucian pada Depkes RI 2006 dengan prosentase skor $58,94 \%$, walaupun masih banyak aspek yang harus dibenahi.

Hasil pemeriksaan Escherechia coli pada alat makan (gelas) yang digunakan oleh pedagang es dawet di Kecamatan Sokaraja Kabupaten Banyumas, semua sampel tidak memenuhi syarat karena dalam Permenkes No. 1096/MENKES/PER/VI/2011 yang disajikan dalam pernyataan jasa boga bahwa untuk persyaratan peralatan makan angka kuman pada alat makan 0 (nol) dan tidak mengandung E.coli. sampel gelas Toh ditemukan 50, sampel gelas An 230, sampel gelas Dar 230, sampel gelas Sul >24.000 dan sampel gelas Fua 3500.

Peneliti menyarankan untuk peneliti selanjutnya agar melakukan penelitian dengan alat makan yang berbeda dan bakteri selain Escherechia coli.

\section{DAFTAR PUSTAKA}

Adams M, Motarjemi Y. 2004.Dasar-dasar Keamanan Untuk Petugas Kesehatan.Jakarta : Buku Kedkteran EGC.

Anwar dkk.1989. Pedoman Bidang Sanitasi Makanan dan Minuman. Jakarta : Pusat Pendidikan Tenaga Kesehatan Departemen Kesehatan RI.

1990. Pedoman Bidang Studi Makanan dan Minuman Pada Instansi Tenaga Sanitasi. Jakarta.

1996. Sanitasi Makanan Dan Minuman Pada Institusi Pendidikan. Jakarta: Departemen Kesehatan Republik Indonesia.

Anonym. http ://www.lezat.com/resep-minumanlezat/resep-dawet-ayu-Resep-Makanan-LezatMakanan-Lezat-ResepKue-Lezat-RestoranLezat-Tempat-Makanan-Lezat-KulinerLezat.html diakses pada tanggal 10 februari 2015 pukul 08.39 WIB

Azrul, Azwar. 1996. Pengantar Ilmu Kesehatan Lingkungan. Mutiara Sumber Widya, Jakarta.

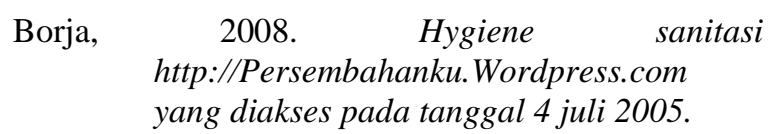

Buckle, et. Al. 2010. Ilmu Pangan. Jakarta : Universitas Indonesia.

Candra, Budiman. 2006. Pengantar Kesehatan Lingkungan. Penerbit Buku Kedokteran EGC. Jakarta

2007. Pengantar Kesehatan Lingkungan. Jakarta : Penerbit Buku Kedokteran EGC.

Depkes RI, 1989. Dinas Kesehatan Provinsi Jawa Tengah. Tentang Pedagang Kaki Lima.

1989. Permenkes RI No. 304 Tentang Persyaratan Kesehatan Rumah Makan dan Restoran.

1990. Permenkes RI No. 416 Tentang Syarat-syarat Dan Pengawasan Kualitas Air.

, 2003. Keputisan Mentri Kesehatan RI No. 1096/MENKES/PER/2011 Tentang

Pedoman Persyaratan Hygiene Sanitasi Jasaboga, Jakarta : Depkes RI

2003. Permenkes RI No. 715/Menkes/SK/V/2003. Tentang Pedagang Kaki Lima.

2006. Kumpulan Modul Kursus Higiene Sanitasi Makanan dan Minuman : Jakarta

2010. Kumpilan Modul Kursus Hygiene Sanitasi Makanan dan Minuman, Jakarta Depkes RI

, 2011. Permenkes RI 1096 Tentang Hygiene Sanitasi Jasa Boga

Fathonah Siti. 2005. Hygiene dan Sanitasi Makanan. Semarang : Unnes Press.

Hiasinta Purnawijayanti. 2001. Sanitasi Higiene dan Keselamatan Kerja dalam Pengolahan Makanan. Yogyakarta : Kanisius.

Jenie, B.S.L. 1996. "Sanitasi dalam Industri Pangan”, dalam Kumpulan Hand Out Kursus Singkat Keamanan Pangan. Yogyakarta: Pusat Antar Universitas Pangan dan Gizi, Universitas Gadjah Mada.

Kukuh. 2007. Studi kandungan bakteri coliform dan sanitasi peralatan es campur pada Pedagang Kaki Lima Sekolah Dasar di Kecamatan Kembaran tahun 2007. KTI. Jurusan Kesehatan Lingkungan. Politeknik Kesehatan Kemenkes Semarang. 
Nurwantoro, dkk.1997. Mikrobiologi Pangan Hewan dan Nabati. Yogyakarta : Penerbit Kaninus.

Pohan, 2009. Pemeriksaan Escherechia coli pada Usapan Peralatan Makan Yang Digunakan Oleh Pedagang Makanan Di Pasar Petisah Medan. Skripsi. Fakultas Kesehatan Masyarakat. Universitas Sumatra Utara Medan.

Pulung, 2013. Studi Kontaminasi E.coli Pada Peralatan Makan yang Digunakan Oleh Pedagang Kaki Lima Di Alun-alun Banjarnegara Tahun 2013. KTI. Jurusan Kesehatan Lingkungan. Politeknik Kesehatan Kemenkes Semarang.
Purbowarsito. 2011. Uji Bakteriologis Air Sumur di Kecamatan Semampir Surabaya. Skripsi Sains Bidang Biologi, Fakultas Sains dan Teknologi, Universitas Airlangga

Sunarjo, 1994. Penyehatan Air Dalam Program Penyediaan dan Pengolahan Air Bersih, Jakarta.

Srikandi Fardiaz. 1992. Analisis Mikroba Pangan 1. Jakarta: Gramedia Pustaka Utama.

Wahyu Hidayat. https://gedangmatikenekvirus. wordpress.com/2011/04/08/mikrobiologisair-2/ diakses pada tanggal 17 januari 2015 Pukul 16.15 WIB.

WHO. 2002. Penyakit Bawaan Makanan. Jakarta : Buku Kedokteran EGC. 